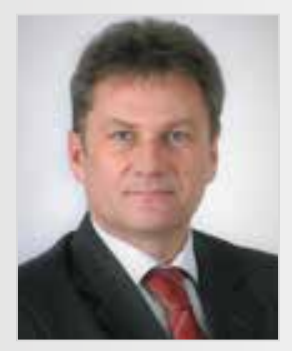

Szerzó:

\section{DR. SZABÓ ZOLTÁN}

A Szent István Egyetem Georgikon Campus Gazdaságmódszertani Tanszék Területfejlesztési és Menedzsment Csoport egyetemi adjunktusa, a Magyar Tudományos Akadémia köztestületi tagja, a Magyar Fürdővárosok Szövetsége ügyvezető elnöke, a Fürdő́városok Tudományos Kutatóintézetének vezetője. A turizmus versenyszférában 10 évet, a középfokú oktatásban 5 évet, az önkormányzati turisztikai igazgatásban 10 évet és a felsőoktatásban föállásban 10 évet, mellékállásban előtte 10 évet töltött. Oktatói pályája során a turizmusmenedzsment szinte minden szakterületét oktatta. Munkájában meghatározó a fürdőturizmushoz kapcsolódó egészségmegőrzés kutatása. Több évtizedes turisztikai szakmai tapasztalata, felsőoktatási gyakorlata és a fürdőturizmus tudományos kutatásában elért eredményei, valamint a nemzeti és nemzetközi tudományos életben betöltött tudományszervező, diszciplínafejlesztô szerepe iskolateremtő.

Levelezési cím: 8380 Keszthely, Deák Ferenc utca 14.

Szabo.Zoltan.dr@szie.hu

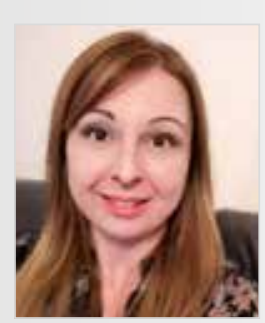

Rovatvezető:

MATÓ-JUHÁSZ

ANNAMÁRIA

Miskolci Egyetem

Gazdaságtudományi Kar

Whole life balance specialista efkegtur@uni-miskolchu egyetemi tanársegéd, Ph.D hallgató

kutatási terület: Az egészségtudatos magatartás fejlesztése a társadalmi marketing eszközeivel juhasz.ancsa@uni-miskolc.hu

\title{
Az egészségmegőrzés motivációjú turisztikai utazások változásai
}

\section{Changes in health preservation motivated tourism travels}

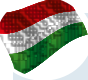

ÖSSZEFOGLALÁS: Világviszonylatban felértékelődtek az egészségmegőrzéssel kapcsolatos turisztikai utazások. Az eddigi kutatások kevés figyelmet fordítottak az utóbbi időben a magyar lakosság egészségmegőrzéshez kötődő belföldi utazásaira. A jelen kutatás célja feltárni a magyar lakosság egészségmegőrzés motivációjú belföldi utazásainak változását a 2015-2019 közötti években, az egészségturizmus fejlesztésére vonatkozólag. Jelen tanulmány a Központi Statisztikai Hivatal szekunder forrásainak elemzésével vizsgálja Magyarországon az egészségmegőrzés motivációjú belföldi utazások változását. Az eredmények alapján megállapítást nyert, hogy az egészségmegőrzéssel összefüggő belföldi utazások jellemzői az utóbbi években jelentősen megváltoztak. A kutatási eredmények ismeretében javasolt az egészségmegőrzéshez kötődő belföldi utazások hatékony növelése érdekében kidolgozni egy új egészségmegőrzési turizmus stratégiát. Kulcsszavak: egészség, tartózkodási idő, turista, vendégéjszaka

ABSTRACT: Tourism travel related to health preservation has become more appreciated worldwide. Researches to lately was paid little attention to the recent domestic health preservation travels of the Hungarian population. Aim of the present study to explore the changes in the Hungarian population's health preservation motivated domestic travels in the years 2015-2019, regarding the development of health tourism. This study examines the changes in health preservation motivated domestic travel in Hungary by analysing the secondary sources of the Central Statistical Office. Based on the results, it was found that the characteristics of domestic travel related to health preservation have changed significantly in recent years. In the light of the research results, it is recommended to develop a new strategy for health-preserving tourism in order to effectively increase domestic travels related to health preservation.

Keywords: guest night, health, length of stay, tourist,

\section{BEVEZETÉS}

Világviszonylatban jelentősen növekszik az egészséggel kapcsolatos szolgáltatások iránti kereslet (Szabó, 2017), amelyet a fejlett országok kórházi rendszereinek válsága, a kórházi szolgáltatások magas ára, a hosszú várólisták és a népesség elöregedése (Dolnicar - Yanamandram - Cli, 2012), valamint a mozgásszervi betegségek emelkedő száma (Hojcska, 2017) okoz. A világ turisztikai kutatói az egészségturizmus további növekedését jelzik előre, elsősorban az emberek életmódjának változásai miatt (Cooper - Vafadari - Hieda, 2015). Napjainkban az egészséggel kapcsolatos utazások olyan irányban fejlődnek, hogy egyre inkább magukban foglalják a jólét növelését és a szabadidőt, mert az egészségmegőrzésben részt vevőknek időre van szükségük a gyógyulásukhoz és a felépülésükhöz (Andó Fritz - Patakiné, 2019, Gianfaldoni et al., 2017). $\mathrm{Az}$ egészséggel kapcsolatos turizmus magában foglalja az egészségügyi ellátást, az utazást, a turizmust, a rekreációt és a wellnesst (Kocsis Fritz - Magyar, 2019, Hoheb, 2017). Tehát az egészségügyi turista ebben az összefüggésben olyan turista, aki a lakóhelyét elhagyva utazik, hogy különböző okokból egészségügyi, orvosi és/ vagy rekreációs szolgáltatásokat vegyen igénybe
(Szabó - Hojcska, 202O). Az eddigi egészségturisztikai tanulmányok túlnyomórészt a nemzetközi turistákra összpontosítottak. A magyar kutatók egészséggel kapcsolatos kutatásai döntő többségben a Magyarországra beutazó turistákra koncentráltak, és kevésbé a belföldi utazásokra (Szabó, 2020). A kutatás célja feltárni az egészségmegőrzés motivációjú belföldi turisztikai utazások utóbbi években végbement változásait és azok ütemét.

\section{ANYAG ÉS MÓDSZEREK}

A kutatás szekunder, mely a Központi Statisztikai Hivatal $(K S H)$ forrásainak elemzésével vizsgálja Magyarországon az egészségmegőrzés motivációjú belföldi utazások változását. A szekunder kutatás adatai megmutatják a magyar lakosság egészségmegőrzésének turisztikai megvalósulásának mértékét. Jelen tanulmány leíró statisztikai módszerekkel tárja fel az egészségmegőrzéshez kötődő belföldi utazások változását 2015-től 2019. év végéig, kiemelt szerepet adva az adatok változásának ütemét kifejező láncviszonyszámnak $\left(V_{\nu}\right)$. Az egészségmegőrzés motivációjú belföldi turizmus értékeinek szemléltetéséhez egy speciális regressziós görbe, a polinomiális trendgörbe kerül alkalmazásra. 
Az egészségmegőrzéshez kapcsolódó adatok összefüggéseinek feltárására a kvartilisek közül a percentilis kerül felhasználásra, mely megmutatja, hogy az adat a mediántól (50\%) mely irányba mutat eltérést. A zöld nyíl a 64,31\%-nál vagy annál nagyobb értékeknél „magas” jelentésű, a sárga nyíl a 64,31\%-nál alacsonyabb és 32,69\%nál vagy annál nagyobb értéknél „átlagos" jelentésü, a piros nyíl a 32,69\%nál kisebb értékeknél „alacsony” jelentésű (Takács, 2016).

\section{EREDMÉNYEK}

\section{A belföldi utazások és azon belül az egészségmegörzés motivációjú utazások változásai}

Az utóbbi öt év (2015-2019) átlagában 14,5 millió belföldi turisztikai utazás alkalmával a magyar lakosság közel 60 millió vendégéjszakát töltött, az átlagos tartózkodási idejük meghaladta a négy napot $(K S H)$. (1. táblázat) A belföldi utazáson belül az egészségmegőrzés motivációjú utazásokon több mint félmillió turista 2,3 millió vendégéjszakát töltött el, átlagosan 4,4 napos tartózkodással. A belföldi turisztikai utazásokon részt vevő turisták számához viszonyítva az egészségmegőrzés motivációjú utazásban részt vevő turisták száma a 2015-2019 között 2,76\% és 4,70\% között változott. $\mathrm{Az}$ általuk eltöltött vendégéjszakák számának aránya vizsgált időszakban 3,53\% és 4,68\% között mozgott ( $K S H)$. (1. ábra) Az ábrán jól látható, hogy az egészségmegőrzés motivációjú utazások részaránya 2017 óta csökkent a belföldi utazásokhoz viszonyítva. Megállapítható továbbá, hogy az egészségmegőrzés motivációjú turisták részaránya nagyobb mértékben csökkent, mint az általuk eltöltött vendégéjszakák részaránya.

\section{A belföldi utazások és azon belül az egészségmegőrzés motivációjú utazások változása}

Az összes belföldi és azon belül az egészségmegőrzés motivációjú utazások változásának időbeni ütemét vizsgálva megállapítható, hogy a változás átlagos üteme a vizsgált időszakban a vendégéjszaka és a turisták vonatkozásában csökkent, míg az átlagos tartózkodási idő esetében fejlődött (KSH). (2. táblázat) A csökkenés mértéke a vendégéjszaka és a turisták vonatkozásában is nagyobb volt az egészségmotivációjú utazások esetében, mint az összes belföldi utazás vonatkozásában.

\begin{tabular}{|c|c|c|c|c|c|c|}
\hline \multirow{2}{*}{ év } & \multicolumn{2}{|c|}{$\begin{array}{c}\text { Belföldi vendégéjszaka } \\
\text { (nap) }\end{array}$} & \multicolumn{2}{|c|}{$\begin{array}{c}\text { Belföldi turista } \\
\left(\text { fó }^{\prime \prime}\right.\end{array}$} & \multicolumn{2}{|c|}{$\begin{array}{c}\text { Átlagos tartózkodási } \\
\text { idö (nap) }\end{array}$} \\
\cline { 2 - 8 } & Összes & $\begin{array}{c}\text { Egészség- } \\
\text { megörzés } \\
\text { motivációjú }\end{array}$ & Összes & $\begin{array}{c}\text { Egészség- } \\
\text { megőrzés } \\
\text { motivációjú }\end{array}$ & Összes & $\begin{array}{c}\text { Egészség- } \\
\text { megőrzés } \\
\text { motivációjú }\end{array}$ \\
\hline $\mathbf{2 0 1 5}$ & 61975322 & 2326122 & 15253453 & 565808 & 4,06 & 4,11 \\
\hline $\mathbf{2 0 1 6}$ & 58967399 & 2637592 & 14424693 & 628234 & 4,09 & 4,20 \\
\hline $\mathbf{2 0 1 7}$ & 57907926 & 2708668 & 14373820 & 675651 & 4,03 & 4,01 \\
\hline $\mathbf{2 0 1 8}$ & 60295704 & 2126962 & 14385927 & 455222 & 4,19 & 4,67 \\
\hline $\mathbf{2 0 1 9}$ & 59280398 & 2026322 & 14248837 & 393478 & 4,16 & 5,15 \\
\hline átlag & $\mathbf{5 9 6 8 5 3 5 0}$ & $\mathbf{2 3 6 5 1 3 3}$ & $\mathbf{1 4 5 3 7 3 4 6}$ & $\mathbf{5 4 3 6 7 9}$ & $\mathbf{4 , 1 1}$ & $\mathbf{4 , 4 3}$ \\
\hline
\end{tabular}

\section{1. táblázat:}

A belföldi és azon belül az egészségmegőrzés motivációjú utazások. Forrás: Saját szerkesztés

Domestic and within it health-preservation motivated travels. Source: Own editing

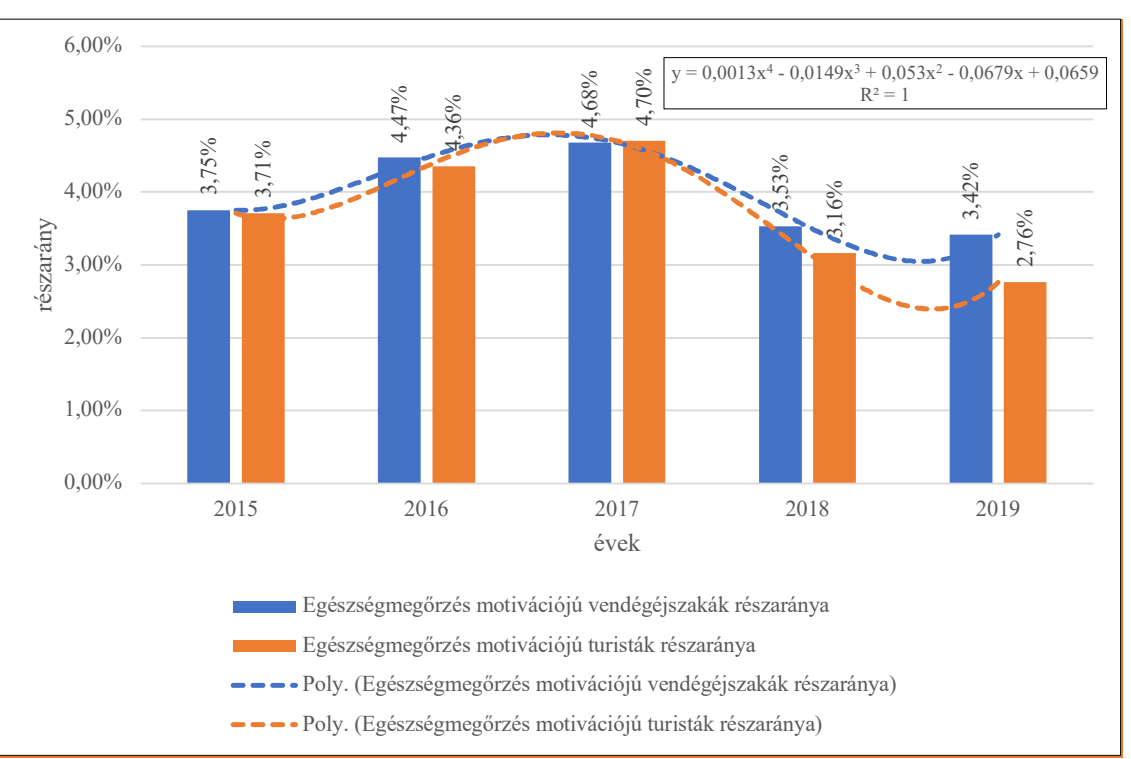

1. ábra: Az egészségmegőrzés motivációjú utazásban részt vevő turisták és vendégéjszakák részarányának változása a belföldi utazásokon belül. Forrás: Saját szerkesztés

Change in the share of tourists and guest nights involved in health-preservation motivated travel within domestic travels. Source: Own editing

\begin{tabular}{|c|c|c|c|c|c|c|}
\hline \multirow{2}{*}{ év } & \multicolumn{2}{|c|}{$\begin{array}{c}\text { Belföldi vendégéjszaka } \\
\text { Láncviszonyszám }\left(V_{\nu}\right)\end{array}$} & \multicolumn{2}{|c|}{\begin{tabular}{c}
\multicolumn{2}{c|}{ Belföldi turista } \\
Láncviszonyszám $\left(V_{\nu}\right)$
\end{tabular}} & \multicolumn{2}{|c|}{$\begin{array}{c}\text { Átlagos tartózkodási idö } \\
\text { Láncviszonyszám }\left(V_{\nu}\right)\end{array}$} \\
\cline { 2 - 7 } & Összes & $\begin{array}{c}\text { Egészség- } \\
\text { megőrzés } \\
\text { motivációjú }\end{array}$ & Összes & $\begin{array}{c}\text { Egészség- } \\
\text { megőrzés } \\
\text { motivációjú }\end{array}$ & Összes & $\begin{array}{c}\text { Egészség- } \\
\text { megőrzés } \\
\text { motivációjú }\end{array}$ \\
\hline $\mathbf{2 0 1 5}$ & & - & - & - & - & - \\
\hline $\mathbf{2 0 1 6}$ & $95,15 \%$ & $113,39 \%$ & $94,57 \%$ & $111,03 \%$ & $100,61 \%$ & $102,12 \%$ \\
\hline $\mathbf{2 0 1 7}$ & $98,20 \%$ & $102,69 \%$ & $99,65 \%$ & $107,55 \%$ & $98,55 \%$ & $95,49 \%$ \\
\hline $\mathbf{2 0 1 8}$ & $104,12 \%$ & $78,52 \%$ & $100,08 \%$ & $67,38 \%$ & $104,04 \%$ & $116,55 \%$ \\
\hline $\mathbf{2 0 1 9}$ & $98,32 \%$ & $95,27 \%$ & $99,05 \%$ & $86,44 \%$ & $99,26 \%$ & $110,22 \%$ \\
\hline átlag & $\mathbf{9 8 , 9 5 \%}$ & $\mathbf{9 7 , 4 7 \%}$ & $\mathbf{9 8 , 3 4 \%}$ & $\mathbf{9 3 , 1 0 \%}$ & $\mathbf{1 0 0 , 6 2 \%}$ & $\mathbf{1 0 6 , 0 9 \%}$ \\
\hline
\end{tabular}

\section{2. táblázat:}

A belföldi és azon belül az egészségmegőrzés motivációjú utazások változásának üteme. Forrás: Saját szerkesztés

Pace of change in domestic and within it health-preservation motivated travels.

Source: Own editing

\subsection{A belföldi utazások és azon belül az egészségmegörzés motivációjú utazások vendégéjszakáinak változása}

A belföldi utazások vendégéjszakáinak átlagos időbeni változásának üteme a vizsgált időszakban visszaesett 98,95\%-ra, és az egészségmegőrzés motivációjú utazások átlagos változásának üteme is visszaesett 97,47\%-ra. Tehát mindkét esetben kismértékü visszaesés volt. Az összes belföldi utazások vendégéjszakái időbeni változásának üteme 2018-ig kismértékben 
fejlődött 104,12\%-ra, majd a vizsgált időszak végére a változás átlagos üteme $(98,95 \%)$ alá esett vissza 98,32\%ra (KSH). (2. ábra) Az egészségmegőrzés motivációjú utazások vendégéjszakái időbeni változásának üteme 2015. évhez viszonyítva 2016-ban (+312 ezer vendégéjszaka) 113,39\%-ra fejlődött. Majd 2017-ben az előző évhez viszonyítva (-71 ezer vendégéjszaka) 102,69\%-ra, 2018-ban az előző évhez viszonyítva ( -582 ezer vendégéjszaka) $78,52 \%$-ra esett vissza. Ezután 2019-ben az előzó évhez viszonyítva (+101 ezer vendégéjszaka) 95,25\%-ra fejlődött, de még így sem érte el az egészségmegőrzés motivációjú utazások vendégéjszakái időbeni változásának átlagos ütemét.

\subsection{A belföldi és azon belül az egészségmegőrzés motivációjú turisták számának változása}

A belföldi turisták száma átlagos időbeni változásának üteme a vizsgált időszakban csökkent 98,34\%-ra, és az egészségmegőrzés motivációjú turisták száma átlagos változásának üteme is csökkent 93,10\%-ra. Vagyis mindkét esetben visszaesés volt, kisebb mértékben az összes belföldi, nagyobb mértékben az egészségmegőrzés motivációjú turisták körében. Az összes belföldi turista száma időbeni változásának üteme 2017-ig kismértékben fejlődött 100,08\%-ra, majd a vizsgált időszak végére a változás átlagos üteme $(98,34 \%)$ alá esett vissza 99,05\%ra $(K S H)$. (3. ábra) Az egészségmegőrzés motivációjú turisták száma időbeni változásának üteme a 2015. évhez viszonyítva 2016-ban (+62.426 fö) 111,03\%-ra fejlődött. Ezután 2017-ben az előző évhez viszonyítva ( -47.417 fó) 107,55\%-ra, 2018-ban az előző évhez viszonyítva (-220.429 fó) 67,38\%-ra esett vissza. Majd 2019-ben az előző évhez viszonyítva (+61.744 fó) 86,44\%-ra fejlődött, jelentősen elmaradva az egészségmegőrzés motivációjú turisták száma időbeni változásának átlagos ütemétől.

\section{A belföldi és azon belül}

\section{az egészségmegőrzés motivációjú turisták átlagos tartózkodási idejének változása}

A belföldi turisták átlagos tartózkodási ideje átlagos időbeni változásának üteme a vizsgált időszakban 100,62\%ra fejlődött, és az egészségmegőrzés motivációjú turisták átlagos tartózkodási ideje átlagos időbeni változásának üteme is fejlődött 106,09\%-ra. Tehát

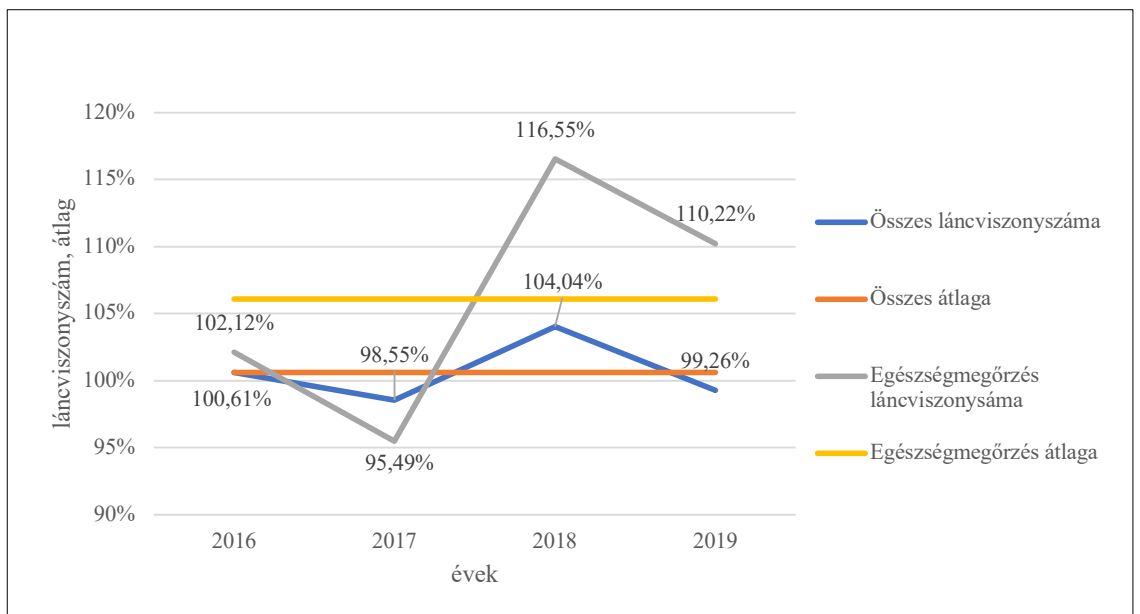

2. ábra:

A belföldi és azon belül az egészségmegőrzés motivációjú utazások vendégéjszakái változásának ütemei és átlagai. Forrás: Saját szerkesztés

Paces and averages of changes in guest nights for domestic and within it health-preservation motivated travels. Source: Own editing

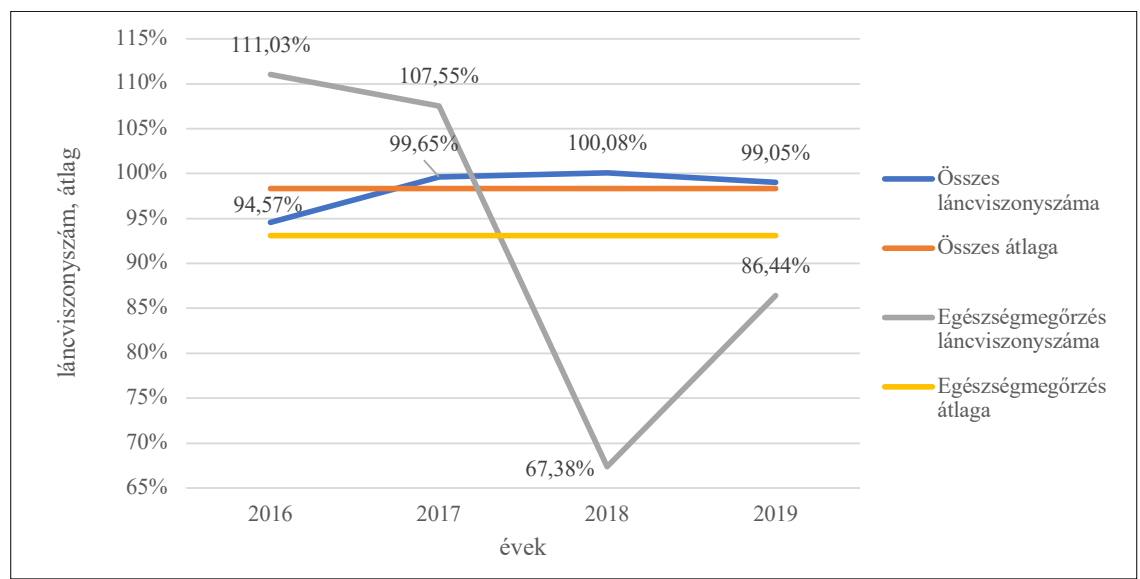

\section{3. ábra:}

A belföldi és azon belül az egészségmegőrzés motivációjú turisták száma változásának ütemei és átlagai. Forrás: Saját szerkesztés

Paces and averages of change the number of domestic and within it health-preservation motivated tourists. Source: Own editing

mindkét esetben fejlődés volt, kisebb mértékű az összes belföldi, nagyobb mértékű az egészségmegőrzés motivációjú turisták körében. Az összes belföldi turista száma időbeni változásának üteme 2017-ig kismértékben fejlődött 100,08\%-ra, majd a vizsgált időszak végére a változás átlagos üteme visszaesett 99,05\%-ra (KSH). (4. ábra) Az egészségmegőrzés motivációjú turisták átlagos tartózkodási ideje időbeni változásának üteme a 2015. évhez viszonyítva 2016-ban 102,12\%-ra fejlődött. Ezután 2017-ben az előző évhez viszonyítva 95,49\%-ra esett vissza. Majd 2018-ban fellendült az előző évhez viszonyítva 116,55\%-ra. Ezután 2019-ben az előző évhez viszonyítva ismét visszaesett 110,22\%-ra, meghaladva az egészségmegőrzés motivációjú turisták száma időbeni változásának átlagos ütemét (106,09\%).

\section{A belföldi és azon belül az egészségmegőrzés motivációjú belföldi utazások összefüggés-vizsgálata}

A belföldi turisták és azon belül az egészségmegőrzés motivációjú turisták száma és az általuk eltöltött vendégéjszakák száma a percentilis vizsgálat segítségével megmutatta, hogy az adat a mediántól (50\%) mely irányba mutat eltérést. A kapott információk azt mutatták, hogy a belföldi turisták száma és az általuk eltöltött vendégéjszakák száma 2016-tól fokozatosan esett vissza „alacsony” szintre. Mivel a turisták számának alacsonyabb szintre való visszaesése jelentősebb volt, mint az általuk eltöltött vendégéjszakáké, ezért az alacsonyabb szintre való visszaesés az átlagos tartózkodási idő vonatkozásában nem jelent meg $(K S H)$ (3. táblázat). 


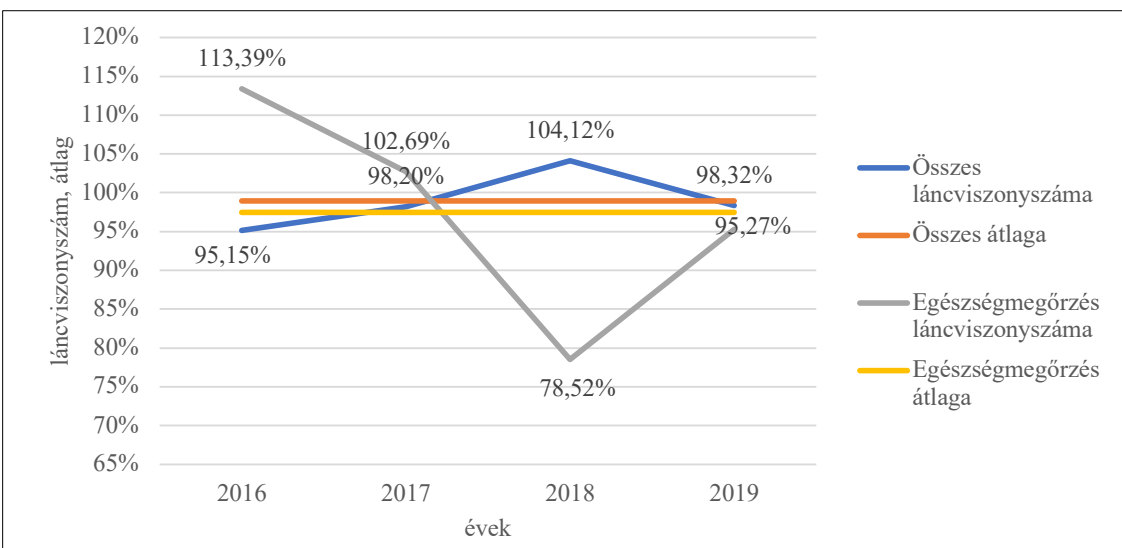

\section{4. ábra:}

A belföldi és azon belül az egészségmegőrzés motivációjú turisták átlagos tartózkodási ideje változásának ütemei és átlagai. Forrás: Saját szerkesztés

Paces and averages of the change in the average length of stay's of domestic and within it health-preservation motivated tourists. Source: Own editing

\begin{tabular}{|c|c|c|c|c|c|c|}
\hline \multirow[b]{2}{*}{ év } & \multicolumn{2}{|c|}{ Belföldi vendégéjszaka (ezer nap) } & \multicolumn{2}{|c|}{ Belföldi turista (ezer fö) } & \multicolumn{2}{|c|}{ Átlagos tartózkodási idő (nap) } \\
\hline & Összes & $\begin{array}{l}\text { Egészség- } \\
\text { megőrzés } \\
\text { motivációjú }\end{array}$ & Összes & $\begin{array}{l}\text { Egészség- } \\
\text { megőrzés } \\
\text { motivációjú }\end{array}$ & Összes & $\begin{array}{l}\text { Egészség- } \\
\text { megőrzés } \\
\text { motivációjú }\end{array}$ \\
\hline 2015 & 61975,322 & $\rightarrow 2326,122$ & 15253,453 & $\rightarrow 565,808$ & 4,06 & 4,11 \\
\hline 2016 & $\downarrow 58967,399$ & 2637,592 & $\downarrow 14424,693$ & 628,234 & 4,09 & 4,20 \\
\hline 2017 & $+57907,926$ & 2708,668 & $\downarrow 14373,820$ & 675,651 & 4,03 & 4,01 \\
\hline 2018 & 60295,704 & $+2126,962$ & $\downarrow 14385,927$ & $\downarrow 455,222$ & 4,19 & 4,67 \\
\hline 2019 & $\rightarrow 59280,398$ & 2026,322 & \& 14248,837 & $\$ 393,478$ & 4,16 & 5,15 \\
\hline
\end{tabular}

\section{3. táblázat:}

A belföldi és azon belül az egészségmegörzés motivációjú belföldi utazások percentilis-vizsgálata. Forrás: Saját szerkesztés

Percentile examination of domestic and, within it, health-preservation motivated domestic travels. Source: Own editing

Az egészségmegőrzés motivációjú belföldi turisták száma és az általuk eltöltött vendégéjszakák száma a percentilis vizsgálat alkalmazásával két jól elkülöníthető szakaszra bontható. Az első szakasz a 2015-2017 év közötti „magas” szintü, a második szakasz a 2018-2019 év közötti ,alacsony” szintü időszak. Az első szakaszban a turisták számának „magasabb” szintre való fejlődése jelentősebb volt, mint az általuk eltöltött vendégéjszakáké, ezért a „magasabb” szintre való fejlődés az átlagos tartózkodási idő vonatkozásában nem jelenik meg. A második szakaszban a turisták számának ,alacsonyabb” szintre való csökkenése jelentősebb, mint az általuk eltöltött vendégéjszakáké, ezért jelenik meg a „magasabb” szintre való fejlődés az átlagos tartózkodási idő vonatkozásában.

\section{KÖVETKETTETÉSEK, JAVASLATOK}

A hazai szakirodalom vonatkozásában kevésbé ismert az egészségmegőrzés motivációjú belföldi turisztikai utazások bemutatása, ezért a végbe- az átlagos tartózkodási idő. Az egészségmegőrzési utazások időbeni változásának két szakasza különíthető el, a 2015-2017 év a fejlődési szakasz, a 2018-2019 év a visszaesési szakasz. A magyarországi egészségmegőrzés motivációjú belföldi turisztikai utazások utóbbi években végbement változásait és azok ütemét megismerve, a szolgáltatók javíthatják a felkészültségüket a piaci lehetőségek jobb kihasználásában és a gazdaságilag hatékonyabb üzemeltetésben.

\section{IRODALOMJEGYZÉK}

Andó, R. - Fritz, P. - Patakiné, B. J. (2019): Életmód-szabadidő-rekreáció. In: Fritz, P. (szerk.) Alapfogalmak és jelentéseik a rekreáció területén: Rekreáció mindenkinek III. Miskolci Egyetemi Kiadó, pp. 10-29.

Cooper, M. - Vafadari, K. - Hieda, M. (2015): Current Trends and Emerging Issues in Medical Tourism; IGI Global Press: Hershey, PA, USA, 430 p. DOI:10.4018/9781-4666-8574-1.

Dolnicar, S. - Yanamandram, V. - Cli, K. (2012) The contribution of vacations to quality of life. Ann. Tour. Res. 39, pp. 59-83.

Gianfaldoni, S. - Tchernev, G. - Wollina, U. - Roccia, M.G. - Fioranelli, M., Gianfaldoni, R. - Lotti, T. (2017): "History of the baths and thermal medicine", Macedonian Journal of Medical Sciences, 5(4), pp. 566-568, DOI:10.3889/oamjms.2017.126

Hoheb, C. (2017): Wellness Tourism. In The Sage International Encyclopedia of Travel \& Tourism; Lowry, L.L., Ed.; Sage: Thousand Oaks, CA, USA, pp. 1433-1436.

Hojeska, Á. E. (2017): A mozgásszervi betegségek prevalenciája és gyógyítási lehetőségei fürdővárosi értékek felhasználásával: The musculosceletal diseases prevalence and healing possibilities using of spa towns values. In: Szabó, Z. (szerk.) The values of spa towns. Szentes, pp. 207-230.

Kocsis, Cs. - Fritz, P. - Magyar, M. (2019): A wellness. In: Fritz, P. (szerk.) Alapfogalmak és jelentéseik a rekreáció területén: Rekreáció mindenkinek III. Miskolci Egyetemi Kiadó, pp. 87-95.

Központi Statisztikai Hivatal (KSH): Jelentés a turizmus és vendéglátás 2015-2019. évi teljesítményéről.

Szabó, Z. - Hojcska, Á. E. (2020): Rekreációs turisztikai fürdőszolgáltatások és azok igénybevételének összefüggés-vizsgálata egy SPA-szolgáltatónál. RECREATION 1O(1) pp. 36-39. DOI: 10.21486/recreation.2020.10.1.

Szabó, Z. (2017): The development offer values of tourism in Hungary: Az egészségturizmus kínálati értékeinek fejlesztése Magyarországon. In: Szabó, Z. (szerk.) The values of spa towns. Szentes, pp. 36-47.

Szabó, Z. (2020): INVESTIGATION CORRELATION STUDY OF THE TOURISTIC USE OF MEDICAL SPA SERVICES IN A HUNGARIAN SPA TOWN. SELYE E-STUDIES 11(2) pp. 59-72.

Takács, Sz. (2016): Bevezetés a matematikai statisztikába, elmélet és gyakorlat. Antarész Kiadó, Budapest, 355 p. 